\title{
KAJIAN MACAM VARIETAS DAN PRODUK OLAHAN SEKAM TERHADAP PERTUMBUHAN DAN PRODUKSI TANAMAN PADI (ORYZA SATIVA L.)
}

\author{
Mariyatul Qibtiyah, Anita Ahliya Permata sari dan Choirul Anam \\ Prodi Agroteknologi Fakultas Pertanian \\ Universitas Islam Darul 'Ulum Lamongan, Jawa Timur \\ email : mariyatulqibtiyah@unisda.ac.id
}

\begin{abstract}
ABSTRAK
Tanaman padi adalah tanaman pokok di Indonesia. Sebagian besar masyarakat di Kabupaten Lamongan pada umumnya mengkonsumsi beras sebagai makanan pokok. Upaya yang dapat dilakukan untuk peningkatan produksi yaitu perluasan area sawah, pengelolaan lahan serta penggunaan varietas unggul dan produk olahan sekam. Penelitian ini bertujuan untuk mengetahui pengaruh macam varietas dan produk olahan sekam terhadap pertumbuhan dan produksi tanaman padi (Oryza sativa L.). Penelitian ini dilaksanakan di Desa Waruwetan, Kecamatan Pucuk, Kabupaten Lamongan. Penelitian dilaksanakan bulan Desember sampai Maret 2019. Penelitian ini dilakukan dengan menggunakan metode rancangan acak kelompok (RAK) faktorial dengan dua faktor perlakuan. Faktor Macam Varietas Terdiri dari tiga perlakuan yaitu: Situ Bagendit (S1), Ciherang (S2), Inpari 32 (S3). Faktor Olahan Sekam terdiri dari tiga perlakuan yaitu: Tanpa olahan sekam (V1), Kompos Sekam 5 t/ha (V2), dan Sekam Bakar 5 t/ha (V3).Indikator pengamatan meliputi: Tinggi tanaman, Jumlah anakan, Jumlah Malai, Bobot Gabah 1000 Butir dan Bobot Gabah Per Hektar. Pengamatan dimulai pada umur 7 hari dan dilanjut 14 hari sekali. Interaksi antar perlakuan berpengaruh nyata terhadap macam varietas dan produk olahan sekam. Kombinasi perlakuan terbaik adalah S3V3 (varietas inpari 32 dan arang sekam 5 t/ha) pada pengamatan tinggi tanaman dan jumlah anakan. Perlakuan varietas berpengaruh baik pada hampir seluruh parameter pengamatan. Produk olahan sekam berpengaruh terhadap tinggi tanaman, jumlah anakan, jumlah malai, bobot 1000 butir.
\end{abstract}

Kata Kunci : Varietas, Padi, Olahan Sekam

\section{PENDAHULUAN}

Tanaman padi adalah komoditas pangan yang menepati posisi pertama di Indonesia dengan tingkat produksi maupun konsumsi menghasilkan beras sebagai makanan pokok masyarakat di Kabupaten Lamongan dan masyarakat Indonesia pada umumnya. Lamongan merupakan basis pertanian di Jawa Timur yang produksi utamanya adalah padi dan jagung. Dengan luas area padi 138.302 Ha, sedangkan luas area jagung 50.864 Ha (BKPM, 2012).
Strategi yang dapat dilakukan untuk peningkatan produksi yaitu perluasan area sawah, perluasan area sawah pengelolaan lahan serta penggunaan varietas unggul dan produk olahan sekam. Varietas unggul padi memiliki sifat yaitu umur genjah, berdaya hasil tinggi, rasa pulen, tahan terhadap dan hama penyakit (Suprihatno et al., 2009).

Aplikasi nitrogen memiliki sifat responsif terhadap variestas unggul serta berumur pendek. Peningkatan laju fotosintesis yang mengakumulasi biomassa lebih tinggi dengan menggunakan varietas padi unggul yang mempunyai karakter fisiologi dan morfologi. Contoh varietas padi 
yang memiliki umur pendek diantaranya varietas Ciherang, IR64 dan Inpari, dll. Tidak semua varietas memiliki adaptasi yang baik di setiap lokasi karena setiap wilayah membutuhkan varietas yang spesifik.

Penggunaan varietas unggul di lahan oleh masyarakat masih terbatas. Menurut Daradjat et al. (2008), bahwa benih padi sebagian dari hasil panen musim sebelumnya masih digunakan oleh masyarakat yang dilakukan berulang-ulang. Sekam merupakan biomassa yang bisa digunakan untuk bahan baku industri, pakan ternak, bahan bakar atau sebagai adsorbsi logam berat. komponen utama sekam padi yaitu selulosa $\quad(31,4-\quad 36,3 \%)$, hemiselulosa $(2,9-11,8 \%)$, dan lignin $(9,5-18,4 \%)$ (Paramita, 2010). Menurut Conover (1980) dalam sekam padi masih mengandung organisme patogen, tetapi memiliki aerasi dan drainase yang baik.. Oleh karena itu media tanam berupa sekam sebelum digunakan maka untuk menghancurkan patogen sekam harus dibakar terlebih dahulu. Penelitian ini bertujuan untuk mengetahui pengaruh macam varietas dan produk olahan sekam terhadap pertumbuhan dan produksi tanaman padi (Oryza sativa L.)

\section{METODOLOGI PENELITIAN Tempat dan Waktu}

Penelitian ini dilaksanakan di Desa Waru-wetan, Kecamatan Pucuk, Kabupaten Lamongan. Ketinggian tempat $\pm 6 \mathrm{~m} \mathrm{dpl}$. Pelaksanaan penelitian pada bulan Desember sampai Maret 2019.

\section{Bahan dan Alat}

Bahan yang digunakan dalam penelitian ini yaitu benih padi Situ Bagendit, Ciherang dan Inpari 32, olahan sekam, pupuk majemuk, pupuk organik, dan pestisida pengendali hama dan penyakit. Alat yang digunakan yaitu cangkul, sabit, pisau, timbangan, meteran, sprayer, gunting, alat-alat tulis, papan nama, terpal, dan penunjang lainnya.

\section{Metode Penelitian}

Penelitian menggunakan metode rancangan acak kelompok (RAK) faktorial dengan 2 faktor perlakuan, faktor pertama yaitu Macam Varietas yang terdiri dari : S1 (Situ Bagendit); S2 (Ciherang); S3 (Inpari 32), faktor kedua yaitu Olahan Sekam yang terdiri dari : V1 (Kontrol); V2 (Kompos Sekam 5 t/ha); V3 (Arang Sekam 5 t/ha).

\section{Pelaksanaan Penelitian}

\section{Pembuatan Arang Sekam dan kompos sekam}

\section{- Pembuatan arang sekam}

Dibuat gundukan sekam mengelilingi pipa seng dimana pipa tersebut berdiri dan berada ditengah-tengah gundukan sekam. Dimasukkan koran kedalam pipa pembakaran kemudian api dinyalakan. Setelah 20-30 menit puncak timbunan sekam menghitam, dinaikkan sekam ke arah puncak yang masih berwarna coklat. Setelah sekam menghitam, disiram air sampai merata. Setelah suhunya menurun, gundukan arang sekam dibongkar dan dikeringkan kemudian dimasukkan kedalam karung.

\section{- Pembuatan Kompos Sekam}

Mencampurkan sekam dengan EM4, gulas tetes dan air. Kemudian ditutup dengan plastik selama 1 bulan. Jika suhu terlalu panas, maka setiap 1 minggu sekali dibuka penutup dan dibolak balik bahan kompos tersebut dan kemudian ditutup kembali. Setelah 1 bulan kompos sekam siap digunakan. Jika proses fermentasi berjalan dengan baik, maka bahan- bahan tersebut akan berubah warna menjadi gelap/hitam kecoklatan dan tidak berbau menyengat.

\section{Pengolahan Tanah}

Tanah dilakukan pembersihan, pembajakan, dan pencangkulan. Setelah itu dilakukan pembuatan petakan dengan ukuran $2 \mathrm{~m}$ x $2 \mathrm{~m}$ sebanyak 27 petakan 
dan dibuatkan saluran air sekaligus sebagai pembatas antar petak dan ulangan.

\section{Persemaian}

Benih padi yang digunakan yaitu Situ bagendit, Ciherang, Inpari 32. Persemaian dilakukan pertama dengan merendam benih didalam air selama 24 jam, setelah benih padi mulai ada titik tumbuh, kemudian di taburkan di atas tanah persemaian yang telah disiapkan. Setelah padi berumur 20 hari padi siap dipindah tanam ke lahan.

Pemberian Arang Sekam dan Kompos Sekam

Pemberian arang sekam dan kompos sekam dilakukan pada pagi hari 1 minggu sebelum penanaman kemudian bibit siap ditanam. Arang sekam dan kompos sekam dihamparkan pada bedengan percobaan dengan dosis 5 ton/ha.

\section{Penanaman}

Penanaman dilakukan langsung dengan kedalaman $3 \mathrm{~cm}$ dan kondisi air macak-macak. Penanaman dengan posisi bibit tegak dengan jumlah tanaman satu lubang 3 bibit/rumpun dengan tanaman yang sesuai dengan perlakuan.

\section{Pemupukan}

Jenis dan dosis pupuk yang digunakan yaitu Phonska (150 kg/ha) dan Urea $(50 \mathrm{~kg} / \mathrm{ha})$. Pemberian pupuk dilakukan sebanyak 2 kali selama musim tanam dengan pembagian $(75 \mathrm{~kg} / \mathrm{ha})$ Phonska dan (25 kg/ha) Urea diberikan pada umur 20 hst. Selanjutnya pemupukan kedua diberikan pada umur 35 hst dengan Phonska (75 kg/ha) dan Urea (25 kg/ha).

\section{Pengendalian OPT (organisme Pengganggu Tanaman)}

Pengendalian hama penyakit tanaman dilakukan secara terpadu dengan mengutamakan pengamatan dilakukan secara berkesinambungan.

\section{Pengamatan dan pengolahan data}

Indikator yang diamati adalah tinggi tanaman, jumlah anakan, jumlah malai, bobot gabah 1000 butir, bobot gabah per hektar. Pengamatan dilaksanakan mulai umur 7 hst selanjutnya dilakukan 14 hari sekali. Data pengamatan dianalisa dengan uji Fhisher (uji F) $5 \%$ dan $1 \%$ jika terdapat perbedaan nyata dilanjutkan dengan uji Beda Nyata Terkecil (BNT 5\%).

\section{HASIL DAN PEMBAHASAN Tinggi Tanaman}

Hasil analisa ragam menunjukkan adanya interaksi antara perlakuan macam varietas dan olahan sekam terhadap tinggi tanaman pada umur 35 hst dan 49 hst. Sedangkan pada pengamatan umur $7 \mathrm{hst}$ dan 21 hst tidak terdapat interaksi. Ratarata tinggi tanaman terdapat pada Tabel 1.

Tabel 1. Rata-rata tinggi tanaman pada pengamatan umur 35 Hst dan $49 \mathrm{Hst}$.

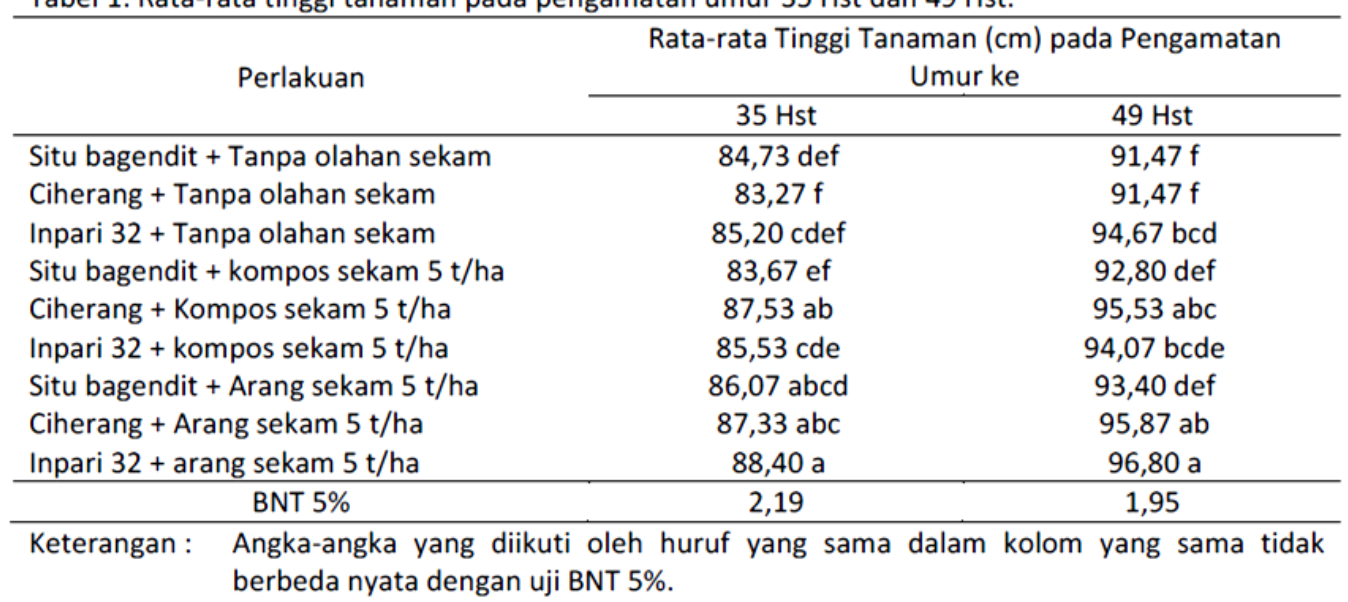


Pada tabel 1, Menunjukkan kombinasi perlakuan dengan hasil terbaik terdapat pada perlakuan varietas inpari 32 dan arang sekam 5 t/ha. Hal ini karena masing-masing varietas memiliki ciri dan sifat khusus berbeda dan dapat diketahui bahwa pemberian arang sekam dapat memperbaiki fisik tanah seperti menggemburkan tanah sehingga unsur hara di dalam tanah dapat membantu akar menyerap nutrisi, memperbaiki ruang pori tanah selain itu juga dapat memperbaiki sifat kimia tanah dengan meningkatkan $\mathrm{pH}$ tanah dan menyediakan unsur hara.

Menurut Aroning (2005), bahwa bahan organik dalam tanah selain menambah hara dalam tanah, dapat membantu struktur tanah sehingga aerasi tanah menjadi lebih baik yang memungkinkan akar lebih berkembang, sehingga volume akar menjadi besar dan kemampuan menyerap hara menjadi lebih besar.

Tabel 2. Rata-rata Jumlah Anakan Pada Pengamatan Umur 35 Hst dan 49 Hst.

\begin{tabular}{|c|c|c|}
\hline \multirow{2}{*}{ Perlakuan } & \multicolumn{2}{|c|}{ Rata-rata Jumlah Anakan pada Pengamatan Umur ke } \\
\hline & $35 \mathrm{Hst}$ & $49 \mathrm{Hst}$ \\
\hline Situ bagendit + Tanpa olahan sekam & $21,87 \mathrm{bc}$ & 24,87 bcde \\
\hline Ciherang + Tanpa olahan sekam & $19,47 \mathrm{f}$ & $23,33 \mathrm{~g}$ \\
\hline Inpari 32 + Tanpa olahan sekam & 20,80 cdef & 24,60 bcdef \\
\hline Situ bagendit + kompos sekam $5 \mathrm{t} /$ ha & 20,93 cde & 24,87 bcde \\
\hline Ciherang + Kompos sekam 5 t/ha & 21,53 bcd & $25,47 \mathrm{ab}$ \\
\hline Inpari $32+$ kompos sekam 5 t/ha & $21,87 \mathrm{bc}$ & $25,33 \mathrm{abc}$ \\
\hline Situ bagendit + Arang sekam 5 t/ha & $22,07 \mathrm{~b}$ & $25,07 \mathrm{bcd}$ \\
\hline Ciherang + Arang sekam 5 t/ha & $22,07 \mathrm{~b}$ & $25,33 \mathrm{~g}$ \\
\hline Inpari $32+$ arang sekam 5 ton/ha & 23,20 a & 26,40 a \\
\hline BNT 5\% & 1,11 & 0,85 \\
\hline $\begin{array}{l}\text { Angka-angka yang dii } \\
\text { berbeda nyata dengan }\end{array}$ & $\begin{array}{l}\text { eh huruf yang si } \\
5 \% \text {. }\end{array}$ & m yang sama tid \\
\hline
\end{tabular}

Keunggulan arang sekam yaitu dapat melindungi tanaman serta memperbaiki sifat fisik dan kimia tanah.

Selain pengaruh dari sekam yang diberikan ke tanaman padi, varietas adalah faktor yang menentukan dalam pertumbuhan dan produksi tanaman padi karena setiap varietas mempunyai sifat genetis, morfologis, maupun fisiologis yang berbeda (anonymous, 2013). Keragaman penampilan tanaman dipengaruhi oleh susunan genetik tanaman.

\section{Jumlah Anakan}

Hasil analisa ragam menunjukkan adanya interaksi antara penggunaan varietas dan olahan sekam terhadap jumlah anakan pada umur 35 hst dan 49 hst Sedangkan pada pengamatan umur 21 hst tidak terdapat interaksi. Rata-rata Jumlah anakan terdapat pada

Pada tabel 2, menunjukkan bahwa pada parameter pengamatan jumlah anakan menunjukkan kombinasi perlakuan dengan hasil terbaik terdapat pada perlakuan varietas inpari 32 dan arang sekam 5 t/ha. Pertumbuhan genetik ketiga varietas berbeda sehingga ekspresi sifat pertumbuhan dan perkembangan jumlah anakan tidak sama antar varietas. 
Menurut Cepy dan wayan (2011) tinggi rendahnya pertumbuhan serta hasil tanaman dipengaruhi oleh 2 faktor yaitu internal yang meliputi sifat genetik atau keturunan tanaman dan eksternal yaitu faktor lingkungan seperti iklim tanah dan faktor abiotik.

Hal tersebut sejalan dengan penelitian dari Anhar et al., (2016) yang menyatakan bahwa jumlah anakan dan tinggi tanaman yang berbeda dikarenakan setiap varietas memiliki sifat gen yang berbeda-beda.

Pemberian bahan organik ke dalam tanah dapat memberikan makanan bagi jasad renik tanah dan menambah hara bagi tanaman sehinga akan lebih mendorong prtumbuhannya.
Peranan arang sekam padi dapat memperbaiki struktur tanah akibat dari aerase dan drainase yang baik, unsur hara yang tersedia dimanfaatkan tanaman untuk proses metabolisme yang akhirnya mempengaruhi pembentukan anakan tanaman padi. Pemberian arang sekam padi selain dapat memperbaiki aerase dan drainase tanah, juga dapat menyediakan unsur hara penting seperti N, P dan K yang dibutuhkan tanaman padi dalam pembentukan anakan.

\section{Jumlah Malai}

Hasil analisa ragam menunjukkan adanya perbedaan nyata antara macam varietas dan olahan sekam terhadap jumlah malai pada saat panen. Rata-rata Jumlah malai terdapat pada Tabel 3.

Tabel 3. Rata-rata Jumlah Malai.

\begin{tabular}{|c|c|}
\hline Perlakuan & Rata-rata Jumlah malai \\
\hline Situ bagendit & $15.33 \mathrm{~b}$ \\
\hline Ciherang & $15.82 \mathrm{~b}$ \\
\hline Inpari 32 & $16.69 \mathrm{a}$ \\
\hline BNT $5 \%$ & 0.83 \\
\hline Tanpa olahan sekam & $15.44 \mathrm{~b}$ \\
\hline Kompos sekam 5 t/ha & $15.69 \mathrm{~b}$ \\
\hline Arang sekam 5 t/ha & $16.71 \mathrm{a}$ \\
\hline BNT 5\% & 0.83 \\
\hline $\begin{array}{ll}\text { Keterangan: } & \begin{array}{l}\text { Angka-angka } \\
\text { berbeda nyata }\end{array}\end{array}$ & ima dalam kolom yang sama tidak \\
\hline
\end{tabular}

Pada tabel 3, menunjukkan bahwa hasil terbaik terdapat pada perlakuan varietas inpari 32 dan pemberian arang sekam 5 t/ha. Terdapat korelasi antara jumlah malai dengan hasil bahwa semakin tinggi jumlah malai maka hasil tanaman padi akan semakin tinggi juga. sejalan dengan penelitian Mulyadi (2008) bahwa hasil tanaman berkorelasi positif nyata terhadap jumlah malai. Jumlah anakan produktif dan umur berbunga berpengaruh terhadap jumlah malai dimana penyerbukan akan berhasil apabila menghasilkan banyak padi yang bernas.

Berkaitan dengan hal tersebut Arang sekam dapat meningkatkan aktivifas mikroorganisme untuk membantu proses perombakan bahan organik sehingga tanaman yang membutuhkan unsur hara menjadi meningkat dan memungkinkan tanaman pada fase vegetatif mengalami pertumbuhan dan perkembangan yang lebih baik. 
Menurut

Kesumaningwati

Roro

(2014), pemanfaatan sisa panen berupa bokashi sekam pada tanah sawah mampu meningkatkan $\mathrm{pH}$ tanah walaupun tidak besar peningkatannnya.

Perlakuan arang sekam dapat mendukung perbaikan sifat fisik, kimia dan biologi tanah, dengan lingkungan yang baik serta $\mathrm{pH}$ tanah yang menguntungkan. Menurut Sugiyanta (2007), meningkatnya laju pertumbuhan tanaman padi dipengaruhi oleh unsur hara makro maupun mikro di dalam tanah, unsur hara makro $\mathrm{N}, \mathrm{P}$ dan $\mathrm{K}$ dalam jumlah cukup dapat meningkatkan laju pertumbuhan tinggi tanaman, jumlah anakan dan produksi gabah tanaman padi.

\section{Bobot Gabah 1000 butir (g)}

Hasil analisa ragam menunjukkan adanya hasil perbedaan nyata antara perlakuan macam varietas dan olahan sekam terhadap bobot gabah 1000 butir pada saat panen. Ratarata bobot gabah 1000 butir terdapat pada Tabel 4.

Tabel 4. Rata-rata Bobot Gabah 1000 butir.

\begin{tabular}{lc}
\hline \multicolumn{1}{c}{ Perlakuan } & Rata-rata bobot gabah 1000 butir $(\mathrm{g})$ \\
\hline Situ bagendit & $0,037 \mathrm{c}$ \\
Ciherang & $0,042 \mathrm{~b}$ \\
Inpari 32 & $0,051 \mathrm{a}$ \\
\hline BNT 5\% & 0,004 \\
\hline Tanpa olahan sekam & $0,042 \mathrm{ab}$ \\
Kompos sekam 5 t/ha & $0,041 \mathrm{~b}$ \\
Arang sekam 5 t/ha & $0,046 \mathrm{a}$ \\
\hline BNT 5\% & 0,004 \\
\hline
\end{tabular}

Keterangan: Angka-angka yang diikuti oleh huruf yang sama dalam kolom yang sama tidak berbeda nyata dengan uji BNT $5 \%$.

Pada tabel 4, Menunjukkan bahwa hasil terbaik ditunjukkan pada perlakuan varietas inpari 32 dan pemberian arang sekam 5 t/ha. Hal ini dikarenakan berat 1000 biji ditentukan oleh faktor genetik sehingga bentuk dan ukuran biji yang dihasilkan sama. Bahan kering yang terkandung dalam biji sangat berpengaruh terhadap tinggi rendahnya berat biji. Fotosintesis sangat berpengaruh terhadap bahan kering biji yang selanjutnya akan digunakan untuk pengisisan biji, sesuai dengan pendapat Rahimi (2011) menyatakan bahwa bobot biji suatu varietas ditentukan oleh bentuk dan ukuran biji.

Faktor genetik sanagt berperan apabila tidak terjadi perbedaan ukuran biji .Selain faktor genetik tanaman, faktor lingkungan juga mempengaruhi pertumbuhan tanaman. Darwis (1979) juga menambahkan bahwa berat 1000 butir gabah merupakan ciri yang stabil dari suatu varietas, besarnya butir juga ditentukan oleh ukuran kulit yang terdiri dari lemma dan pallea.

Dengan pemberian arang sekam pada fase generatif dapat menyumbangkan unsur hara $\mathrm{P}, \mathrm{K}$ yang digunakan dalam proses pembentukan biji tanaman padi. Ketersediaan unsur hara $\mathrm{P}$ pada proses pembentukan biji sangat diperlukan oleh tanaman, unsur hara $\mathrm{P}$ dibutuhkan tanaman padi untuk mendukung proses pemasakan buah dan nantinya berpengaruh terhadap berat 1000 butir gabah tanaman padi.

\section{Bobot Gabah Per Hektar}

Hasil analisa ragam menunjukkan adanya hasil perbedaan nyata pada perlakuan macam varietas terhadap bobot gabah per hektar pada saat panen. Rata- 
rata bobot gabah per hektar

terdapat pada Tabel 5.

Tabel 5. Rata-rata Bobot Gabah Per Hektar.

\begin{tabular}{|c|c|}
\hline Perlakuan & Rata-rata Bobot Gabah Per Hektar (ton) \\
\hline Situ bagendit & $1,46 \mathrm{~b}$ \\
\hline Ciherang & $1,51 \mathrm{~b}$ \\
\hline Inpari 32 & $1,67 \mathrm{a}$ \\
\hline BNT $5 \%$ & 0,13 \\
\hline
\end{tabular}

Pada tabel 5, menunjukkan bahwa hasil terbaik ditunjukkan pada perlakuan varietas inpari 32 . Hasil gabah dari varietas tersebut bervariasi dari 1,46-1,67 t/ha, karena ditentukan dari pendek dapat memberikan hasil yang tinggi. Menurut Astanto Kasno, et al., (1995), Varietas merupakan kelompok tanaman yang memiliki ciri khas seragam dan stabil serta mengandung perbedaan jelas dari varietas lain, sehingga masing-masing varietas mempunyai sifat khusus antara lain keunggulan agronomi.

Varietas unggul memiliki sifat pembawaan yang dapat menghasilkan produksi tinggi, respon terhadap pemupukan dan tahan hama penyakit. Pada saat penelitian potensi varietas unggul dipengaruhi oleh interaksi antara varietas dengan kondisi lingkungan. Oleh karena itu, faktor lingkungan seperti iklim dan tanah sangat berpengaruh terhadap produksi hasil tanaman. Jenis varietas dengan keadaan lingkungan yang sesuai diharapkan dapat tumbuh baik dan menghasilkan produsi tinggi.

\section{KESIMPULAN}

Berdasarkan hasil

penelitian dan pembahasan didapat hasil bahwa penggunaan varietas inpari 32 dan arang sekam 5 t/ha dapat menghasilkan peningkatan pertumbuhan dan produksi tanaman padi lebih baik dibandingkan dengan perlakuan lainnya.

jumDAFTAR PLASAnAdkduktif/rumpun dan komponen hasil dari Anonymous,2013.https://warasfarm.wordpr ess.com/2013/07/31/pemanfaatansekam-padi-dalam-sebagai-mediatanam-dan-pupuk/diakses pada tanggal 17 April 2016

Abdullah, M. 2006. "potensi padi liar sebagai sumber genetik dalam pemuliaan Padi". Buletin Iptek Tanaman pangan 1(2): 143-152.

Anhar, R., H. Erita. dan Efendi. 2016. Pengaruh dosis pupuk urea terhadap pertumbuhan dan produksi plasma nutfah padi lokal asal Aceh. Jurnal Kawista. 1(1): 30-36

Aroning, 2005.Aplikasi Berbagai Pupuk Organik Pada Tanaman Kacang Hijau di Lahan Kering.Jurnal Sains \& Teknologi, Agustus 2005. Vol. 5 No. 2: 65

Astanto Kasno, 1995. Perkembangan Varietas Kacang Tanah. Monograt Balittan Malang No. 121993. Malang, 31 hal.Augusts, P., L.A. Taulu, dan D. Polakitan, 2011. Kajian beberapa varietas unggul baru padi sawah di Kabupaten Minahasa. Prosiding Seminar Nasional Serealia, Maros Sulawesi Selatan. Hal. 130-133. 
BKPM, 2012. Gambaran wilayah kabupaten Lamongan. Badan Koordinasi Penanaman Modal. Lamongan.

Cepy dan W. Wayan. 2011. Pertumbuhan dan hasil tanaman padi (Oryza sativa L.) di media vertisol dan entisol pada berbagai teknik pengaturan air dan jenis pupuk. Jurnal Crop Agro 4(2): 49- 56.

Conover, C. A. 1980. Foliage plant. In R.a. larson (Ed): Introduction to floriculture. Academic Press. Inc. New york. $607 \mathrm{p}$.

Daradjat, Suprihatno 2008. Kemajuan Dan Ketersediaan Varietas Unggul padi. Balai Besar Penelitian Tanaman padi. Kementrian Pertanian.

Darwis, S. N. 1979. Agronomi Tanaman Padi. Lembaga Penelitian TanamanPadi.. Perwakilan Padang. Jilid I

Mulyani, $\quad$ Sri. 2006.

Anatomi Tumbuhan. Kanisius. Yogyakarta.

Paramita, A. (2010). Sekam Padi, Sumber Energi Unik yang Mulai Dilirik. Online. Diambil 26 september 2010 dari http://chapuccino.wordpre ss.com/2010/01/27/sekam -padi-sumber-energiyang-mulai-dilirik/.

Rahimi, Z. Zuhry, E. Nurbaiti. 2011. Pengaruh Jarak
Tanam Terhadap Pertumbuhan dan Produksi Padi Sawah (Oryza sativa L.) Varietas Batang Piaman dengan Metode System of Rice Intensification (SRI) di Padang Marpoyan Pekanbaru. Jurnal. Fakultas Pertanian. Universitas Riau. Hal 7.

Roro Kesumaningwati. 2014. Pemanfaatan sisa panen dalam bentuk bokashi sekam Terhadap peningkatan beberapa sifat kimia (ph, c organik, n, p, dan k) tanah sawah.Fakultas Pertanian Universitas Mulawarman, Samarinda, Kalimantan Timur.

Sugiyanta. 2007. Peran Jerami dan Pupuk Hijau Crotalacia juncea. Terhadap Efisiensi dan Kecukupan Hara Lima Varietas Padi Sawah. Disertasi (Tidak dipublikasikan) IPB. Bogor.

Suprihatno, B., Dradjat, A.A., Satoto, Baehaki, Widiarta, I.N., Setyono, A., Indrasari, S.D., Lesmana, O.S., Sembiring, H. 2009. Deskripsi Varietas Padi. Subang (ID). Balai Besar Penelitian Padi Sukamandi. 